\title{
INFLUENCE OF THE QUALITY OF ACCRUAL FINANCIAL REPORT INFORMATION WITH THE ROLES OF ACCOUNTING INFORMATION SYSTEM AS AN INTERVENING FACTOR
}

\author{
Dyah Purwanti ${ }^{*}$ \\ Ghulbudin Isham Natser \\ Politeknik Keuangan Negara STAN
}

\begin{abstract}
This study aims to find empirical evidence about the role of accounting information system (AIS) as intervening factors that affect the quality of financial reporting information of the government. This study uses a questionnaire that primary data collected from respondents, namely employees of the accounting department of the government units, especially a partner institution in the State Treasury Office (KPPN) 2 Jakarta. Data processing is performed by the method of partial least squares (PLS). The results of this study are the accounting information system has significantly the impact on the quality of government financial reporting information. While the capacity factor of human resources, control data input and application of Government Accounting Standards (SAP) have a significant direct effect on the AIS, is larger when compared to a direct influence on the quality of financial reporting information. Other factors, organizational commitment and internal control system has a significant influence either directly or indirectly on the quality of financial reporting information. The findings of the study are expected to provide input to the government the importance of improving the accounting information system, such as strengthening the capacity of human resources and accounting applications in realizing quality financial information.
\end{abstract}

Keywords: accounting information systems; the quality of financial reporting information; intervening; the Government Accounting Standards

\section{INTRODUCTION}

The financial report is an accountability form of financial management made by the government. The financial report must be made accrding to the Government Accounting Standards to establish the accountability and transparency of the national financial management. The data and information presented in the government financial report are essentially not only for the purpose of accountability report, but also they are beneficial for other purposes.

Related with the definition above, a fair financial report means it is free from errors (freedom from material error, faithful representation) and presented based on applied Accounting Standards (Handayani, 2012, p. 14). The fairness of the government financial report is assessed by Indonesian Supreme Audit Institution (Badan Pemeriksa Keuangan/BPK) thorugh auditing process. Therefore, the auditing results done by BPK will show the quality of the government financial report measured using an auditory opinion (Handayani, 2012, p. 15). In giving its opinions, BPK must consider the aspect of suitability with SAP, 
availability of financial report information disclosure, obedience toward rules and regulations, and effectiveness of internal control system (UU No. 15 Tahun 2004).

The auditing results from BPK related with the government financial report, both from central government (LKPP) and ministries/state agencies (LKKL) published in the Summary of Auditing Results Smemester 1 (IHPS) year 2015 and previously in the Auditing Report (LHP) BPK year 2014 showed that there is a phenomenon of declining quality of the governement financial report. This phenomenon can be seen from the declining number of LKLL which obtain the opinion of Fair without Exceptions (WTP) and increased number of LKLL which get No Opinion (TMP) statement.

Previously, the Auditing Report on LKPP in 2014 (Report on Internal Control System), based on observation and interview results done by BPK, showed there some main constraints in the preparation of accrual applications 2015, such as: there are still two leaders of the ministries/agencies that do not yet show strong commitment to achieve the success of the application of accrual-based accounting and there are seven (one of them is BKKBN/National Agency for Family Planning) who do not yet communicate internally to all of their units related with the application of accrual-based accounting. Besides, from 22 ministries/agencies, not all the human resources involved in the accounting that have attended the training of accrual-based accounting (some of them are Ministry of Workforces and Transportation and BKKBN). In addition, there are 15 ministries/agencies which do not yet provide sufficient budget to hold the training of accrual-based accounting in their environments (one of them is National Defence Agency/Lemhamnas). This information shows that there are still many problems that must be solved related with the commitment of some ministries/state agencies for the application of accrual-based accounting 2015.

Table 1. Factors causing Declined Performance of State Entities by BPK

\begin{tabular}{|l|l|l|}
\hline No. & Problems & Related Entities \\
\hline 1 & $\begin{array}{l}\text { Accounting Information System used to record the credits is not yet } \\
\text { reliable, thus the fairness of credit values in the balance are still in } \\
\text { doubtness }\end{array}$ & $\begin{array}{l}\text { Ministry of } \\
\text { Communication and } \\
\text { Information }\end{array}$ \\
\hline 2 & $\begin{array}{l}\text { Inventory of fixed assets is not yet recorded and reported thoroughly } \\
\text { in Information System of State-owned Goods, Finance, and Assets }\end{array}$ & $\begin{array}{l}\text { Ministry of } \\
\text { Communication and } \\
\text { Information }\end{array}$ \\
\hline 3 & $\begin{array}{l}\text { In term of data and accounting input, the credits are claimed with } \\
\text { having any strong and clear documents and no any reconciliation. }\end{array}$ & $\begin{array}{l}\text { Public Broadcasting } \\
\text { Agency, Indonesian } \\
\text { National Radio } \\
\text { Station }\end{array}$ \\
\hline 4 & $\begin{array}{l}\text { Interrnal control on the credits of PNPB is not yet adequate; the } \\
\text { Internal Supervisor Unit does not yet hold some reviews on the } \\
\text { financial reports, causing many mistakes/leftover in the presentation } \\
\text { of the balance }\end{array}$ & $\begin{array}{l}\text { Ministry of Energy } \\
\text { and Mineral } \\
\text { Resources }\end{array}$ \\
\hline 5 & $\begin{array}{l}\text { The supply and fixed assets recording are not based on physical } \\
\text { inventory and completed with supporting documents, thus the value of } \\
\text { supply and fixed assets cannot be traced well }\end{array}$ & $\begin{array}{l}\text { Ministry of Social } \\
\text { Andonesian National } \\
\text { Archieving Agency, } \\
\text { BPPT, and BKKBN }\end{array}$ \\
\hline
\end{tabular}


Source: adapted from Summary of Auditing Report Semester I 2015 BPK

Based on the presented facts and data above, if they are linked with the quality of the information seen from the opinion of LKKL 2014, it is shown that the ministries/agencies and other government entities are not yet consistent in applying the governemtn accounting based on SAP, they are still weak in controlling their own internals, lack of commitment from the leadership boards, and well as unavailability of both application system and high quality human resources, and low quality of the opinion of LKKL in 2014 ( there are even some which experienced declined performance than the previous year).

Based on the explanation above, it can be implied that the human factor (capacity of the human resources), system application (Accounting Information System), and organizational factors (organizational commitment, implementation of accounting and internal control system, as well as the application of SAP may influence the quality of the information on the government financial report. The research of (Xu, Horn Nord, Daryl Nord, \& Lin, 2003) stated that some crucial factors to obtain high-quality information are Human Factors, System Factors, Organizational Factors, and External Issues. Further, (Xu et al., 2003) concluded 3 (three) most important factors considered as the most influential on the quality of accounting information generated from Accounting Information System (AIS), i.e. Top Management Commitment, The Nature of AIS and Input Control.

$\mathrm{Xu}$ et al. (2003) explained that the organizational commitment in form of leaders' support, organizational culture, and supporting organizational structure become very important factors to show the seriousness and strong commitment to establish a high-quality financial reporting. Accounting Information System (AIS) is designed to achieve the organizational goals. This system has many important roles that require support from the human factors (personal competencies, understanding of data quality, and personal education and training) that will run this application and implement the Accounting process. The unnecessary and unwellimplemented will result in low-quality accounting report and cause negative impacts for a decision-making (Xu, 2015, p. 19). Therefore, the better the application is used (supported with good human resources capacity), the better also the quality of the information/output of the financial report generated.

The Input Control toward the accounting data becomes an important factor to ensure that the input data are correct and precise. The control input is done in form of controls toward the human (user access, data input procedures, and etc.) and the system (review, check and balance). It is to avoid any fatal errors during the input process, so that the output of the financial report will not generate any misled information/ garbage in, garbage out (Xu, 2015, p. 9). Some previous studies focusing on the Units of the Minsitries/State Agencies have been done by (Choirunisah, 2008) and (Aryani, 2013). Choirunisah (2008) in her explorative research stated that the human resources abilities have positive and significant effects toward the information relevancy as an indicator of the quality of the financial report of the units. Aryani (2013) also found that the application of SAP, Internal Control System, use of ICT, Organizational Commitment, and quality of human resources both simultaneously and partially influence the financial report of the units in the Minsiries/State Agencies. 
The studies of (Choirunisah, 2008) and (Aryani, 2013) were done before the govermment issued a rule about the application of accrual-based accounting in 2015. Through this rule, the studies related with the quality of the government finalcial report are still urgently required. A proper accounting system depends on a specific condition in where an organization belongs to. Gordon \& Milner (1976) were the first experts who had successfully formulated a basis for the accounting system information from the perspective of contingency in their work entitled "A Contingency Framework for the Design of Accounting Information Systems" in 1976. They stated that AIS must be designed in flexible ways that it could adjust well with its surrounding environment and organizational structure handled by an organization. In other words, AIS needs to be designed in an adaptive framework to help an organization to achieve its goals, particularly to obtain high-quality financial information.

The roles of information technology and AIS in this modern era have been very significant. The information technology is developed and used by an organization to improve its effectiveness and efficiency Lin \& Edwards 1996 in (Xu et al., 2003, p. 1). In this modern life, where the financial transactions are getting complex, it is required an application/software of financial accounting and reporting to process the data faster and more accurate. In practice, unwell-implemented system will generate low-quality accounting information for both internal and external users and give negative impacts for the decisionmaking process (Xu, 2015, p. 19). Therefore, the built, selected and applied Accounting Information System must be fit with the organizational needs and expected goals. The suitability, nature and functions of the Accounting Information System, starting from the quality of the data input and output will significantly influence the quality of accounting information generated. Aryani (2013) also presented some empirical evidences that AIS'suitability significantly influences the quality of the information data.

The results if multiple-case studies done (Xu et al., 2003) in showed that some crucial factors to obtain high-quality information are Human Factors, System Factors, Organisational Factors, as well as External Issues. Further, $(\mathrm{Xu}, 2003)$ in his dissertation and journal in 2015 conlcued 3 (three) factors considered as the most influential ones toward the quality of accounting information generated by Accounting Information System (AIS) in Australia i.e. Top Management Commitment, The Nature of AIS and Input Control. Xu et al. (2003) explained that the organizational commitment in form of leaders' support, cultural organization, and organizational structure are some to establish high-quality financial reporting. Therefore, without any support from the leadership boards and organization, it is quite imposiible to generate the high-quality information in the financial report.

Input Control toward the accounting data becomes an important factor to ensure that the input data are correct and precise. The control input is done in form of controls toward the human (user access, data input procedures, and etc.) and the system (review, check and balance). It is to avoid any fatal errors during the input process, so that the output of the financial report will not generate any misled information/ garbage in, garbage out $(\mathrm{Xu}, 2015$, p. 9). Other domestic studies have also investigated other factors predicted as influencing the quality of the financial report, such as the application of Government Internal Control System (SPIP) and the application of SAP. Previous studies focusing on the objects of the Ministries and State Agencies particularly in the Units of the Ministries/Agencies have been done by (Choirunisah, 
2008) and (Aryani, 2013). From their explorative research, it is shown that the human resources abilities have significant and positive effects on the information relevancy as an indicator of high-quality information of the financial report within the units. Aryani (2013) also found that the application of SAP, Internal Control System, use of ICT, Organizational Commitment, and quality of human resources both simultaneously and partially influence the financial report of the units in the Ministries/State Agencies.

Based on the explanation of the concepts as well as the results of the previous studies, it is presumed that there is an influence of the human resources variable. Therefore, the authors try to examine the most important factor of the quality of accrual financial report generated by the units of the Ministries/State Agencies, with the following hypotheses:

H1 : The capacity of the human resources positively and significantly influences the Accounting Information System (AIS).

$\mathrm{H} 2$ : The Organizational Commitment positively and significantly influences the Accounting Information System (AIS).

H3: The Input Control positively and significantly influences the Accounting Information System (AIS). H4: The Internal Control positively and significantly influences the Accounting Information System (AIS). H5: The application/implementation of SAP positively and significantly influences the Accounting Information System (AIS).

H6: The application/implementation of Accounting Information System (AIS) positively and significantly influences the quality of the information of financial report.

\section{METHODS}

The research objects were the Units of the Ministries/State Agencies in the scope of the payment of KPPN Jakarta II. The main reason was KPPN Jakarta II had the greates amount of the budget in Indonesia (Online Monitoring SPAN, 2015). In other words, KPPN Jakarta II covered majority of national expenditure in DIPA of all units of the Ministries/State Agencies in Indonesia. Besides, KPPN unit of Jakarta II had the greates and the most complex number of data, transactions and financial reports. The data analysis method used in this research was Multiple Linier Regression Analysis with SMARTPLS 3. Based on the research framework and hypotheses, the model developed was as follows:

$$
\begin{aligned}
& \mathrm{AIS}=\alpha+\beta 1 . \mathrm{KO}++\beta 2 . \mathrm{PI}+\beta 3 . \mathrm{SPI}+\beta 4 . \mathrm{SAP}+\varepsilon \\
& \mathrm{KILK}=\alpha+\beta 1 . \mathrm{AIS1}+\varepsilon
\end{aligned}
$$

Note:

KILK = Quality of Accrual Finalcial report Information

$\mathrm{KSDM}=$ Capacity of Human Resources (KSDM)

$\mathrm{KO}=$ Organizational Commitment $(\mathrm{KO})$

AIS = Accounting Information System (AIS)

PI $\quad=$ Input Control (PI)

SPI = Internal Control System (SPI) 
Influence Of The Quality Of Accrual Financial Report Information With The Roles Of Accounting Information System As An Intervening Factor Dyah Purwanti, Ghulbudin Isham Natser

SAP $=$ Application/Implementation of Accrual SAP (SAP)

a = Constant

$\beta=$ Regression/Correlation coefficient

$\varepsilon \quad=$ Error

The measurement of operational indicators used Likert scale using 5 (five) preferences of answers, i.e. Absoultely Disagree, Disagree, In Doubt, Agree, and Absolutely Agree.

\section{RESULTS AND DISCUSSION}

The validity test is done to identify the accuracy and exactness of the questions in performing theri functions, so that it will be known whether each item of the question is able to achieve the expected goals or not. The validity test uses bivariate correlation analysis. The validity test is done by comparing the values of Pearson Correlation toward the total values of variable construct on each indicator/question of the variables of Capacity of Human Resources, Organizational Commitment, Accounting Infromation System, Input Control, Internal Control System, Application of Government Accounting Standards, and Quality of Accrual Financial Report Information, all of them are greater than $r$ tabel $(0,188)$ and positively correlated with the significance less than 0.05 , so that all indicators are stated as valid.

Table 2. Results of the Validity Test using SmartPLS

\begin{tabular}{|l|l|l|l|l|l|}
\hline & $\begin{array}{l}\text { Original } \\
\text { Sample (O) }\end{array}$ & $\begin{array}{l}\text { Sample } \\
\text { Mean }(\mathbf{M})\end{array}$ & $\begin{array}{l}\text { Standard Deviation } \\
(\text { STDEV) }\end{array}$ & $\begin{array}{l}\text { T Statistics } \\
(\mid \mathbf{O} / \text { STDEV } \mid)\end{array}$ & $\begin{array}{l}\mathbf{P} \\
\text { Values }\end{array}$ \\
\hline KILK & 0.913 & 0.912 & 0.017 & 54.555 & 0.000 \\
\hline KO & 0.873 & 0.871 & 0.022 & 39.943 & 0.000 \\
\hline KSDM & 0.898 & 0.895 & 0.020 & 45.905 & 0.000 \\
\hline PID & 0.881 & 0.880 & 0.027 & 32.321 & 0.000 \\
\hline PSAP & 0.902 & 0.901 & 0.019 & 47.183 & 0.000 \\
\hline AIS & 0.887 & 0.886 & 0.018 & 49.237 & 0.000 \\
\hline SPI & 0.919 & 0.918 & 0.015 & 62.030 & 0.000 \\
\hline
\end{tabular}

The results of reliability test in Table 3 show that all independent variables used in this research are stated as reliable. It is shown by the value of each Cronbach's Alpha of all variables which is greater than 0,7 (Nunnally, 1994 in Ghozali 2013, 48).

Table 3. Results of the Reliability Test using SmartPLS

\begin{tabular}{|l|l|l|l|l|l|}
\hline & $\begin{array}{l}\text { Original } \\
\text { Sample } \\
(\mathbf{O})\end{array}$ & $\begin{array}{l}\text { Sample } \\
\text { Mean } \\
(\mathbf{M})\end{array}$ & $\begin{array}{l}\text { Standard } \\
\text { Deviation } \\
(\text { STDEV })\end{array}$ & $\begin{array}{l}\text { T Statistics } \\
(\mid \mathbf{O} / \text { STDEV })\end{array}$ & $\begin{array}{l}\mathbf{P} \\
\text { Values }\end{array}$ \\
\hline KILK & 0.896 & 0.895 & 0.021 & 42.409 & 0.000 \\
\hline KO & 0.825 & 0.821 & 0.034 & 24.136 & 0.000 \\
\hline KSDM & 0.870 & 0.867 & 0.026 & 33.402 & 0.000 \\
\hline PID & 0.832 & 0.830 & 0.043 & 19.461 & 0.000 \\
\hline PSAP & 0.867 & 0.865 & 0.026 & 32.956 & 0.000 \\
\hline AIS & 0.849 & 0.847 & 0.026 & 33.064 & 0.000 \\
\hline
\end{tabular}




\begin{tabular}{|l|l|l|l|l|l|}
\hline SPI & 0.899 & 0.897 & 0.020 & 44.636 & 0.000 \\
\hline
\end{tabular}

Table 4. Descriptive Statistics of the Resultso f Research Questionnaire

\begin{tabular}{|l|l|l|l|l|l|l|}
\hline $\begin{array}{l}\text { Research } \\
\text { Variable }\end{array}$ & $\begin{array}{l}\text { Number of } \\
\text { Instrument } \\
s\end{array}$ & $\begin{array}{l}\text { Total Theoretical } \\
\text { Value of All } \\
\text { Questions }\end{array}$ & $\begin{array}{l}\text { Mean of } \\
\text { Research } \\
\text { Actual }\end{array}$ & $\begin{array}{l}\text { Average } \\
\text { Standard } \\
\text { Deviation per } \\
\text { Questions }\end{array}$ & $\begin{array}{l}\text { Number of } \\
\text { Responden } \\
\text { ts }\end{array}$ \\
\hline KSDM & 8 & 8 & 40 & 31,587 & 0,56 & 109 \\
\hline KO & 6 & 6 & 30 & 23,294 & 0,59 & 109 \\
\hline AIS & 6 & 6 & 30 & 23,789 & 0,53 & 109 \\
\hline PI & 5 & 5 & 25 & 21,266 & 0,53 & 109 \\
\hline SPI & 8 & 8 & 40 & 31,440 & 0,56 & 109 \\
\hline PSAP & 5 & 5 & 25 & 20,248 & 0,46 & 109 \\
\hline KILK & 14 & 14 & 70 & 56,908 & 0,41 & 109 \\
\hline
\end{tabular}

Source: adapted from SPSS

The descriptive statistics is used to describe the statistics about the variables used in the research. The instruments used to describe them are minimum \& maximum values, actual range of research results, mean, and standard deviation. The following Table 4 shows the descriptive statistics of the variables studied in this research.

\section{Testing using SMART PLS}

The partial least squares (PLS) analysis is done to test the hypothesis number 1, 2, 3, 4, 5, and 6 summarized in equation model 1 and to test the hypothesis 7 summarized in equation model 2 . In the figure 1 and 2, it is shown the relationships between the variables of Capacity of Human Resources, Organizational Commitment, Accounting Infromation System, Input Control, Internal Control System, Application of Government Accounting Standards, and Quality of Accrual Financial Report Information.

Figure 1. Matrix of Relationships between Variables before Bootsrapping

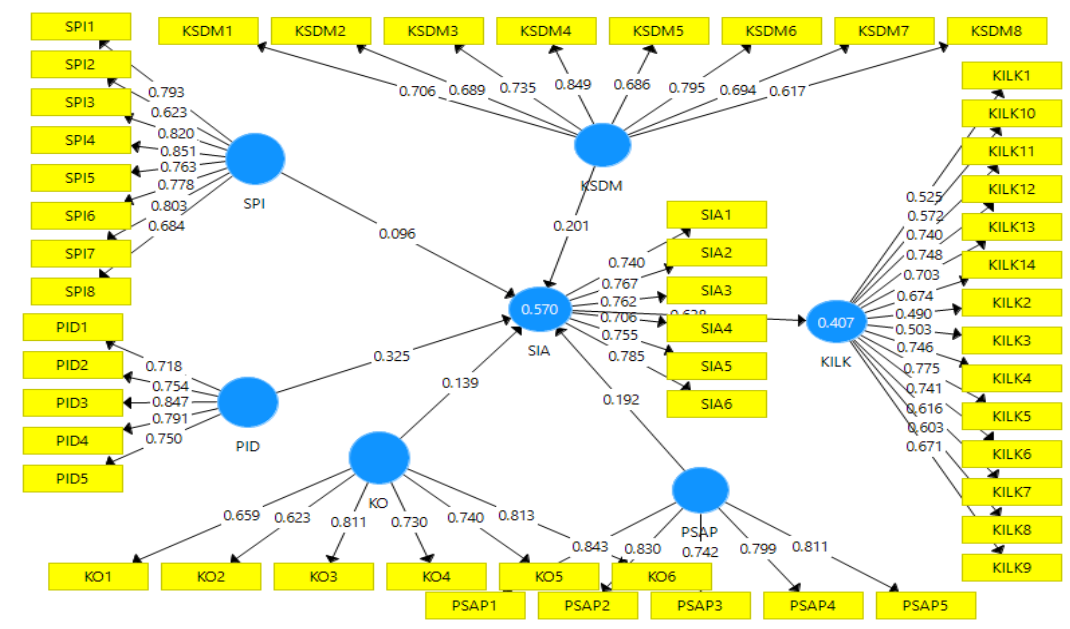

Source : data processing results by SMARTPLS 3 
In the figure 1 above, it can be seen the partial test before bootstrapping for the equation model 1, i.e. the influence of capacity of human resources (KSDM), internal control system (SPI), Data input control (PID), organizational commitment (KO), application of SAP (PSAP) toward the accounting information system (AIS). The capacity of human resources (KSDM), data input control (PID), and application of SAP significantly influence the accounting information system (AIS). Meanwhile, the internal control system and organizational commitment do not have any significant influence toward the accounting information system. The influence of accounting information system (AIS) on the quality of financial report information (KILK) can be seen from the figure 2, where AIS has significant influence on KILK, shown by the coefficient value of 13.809 (> 1.96).

The variables of SPI and KO have t-values respectively as much as 0.746 and $1.240(<1.96)$ thus thy show insignificant effect toward the implementation of accounting information system. Meanwhile, the variables of KSDM, PID and PSAP have t-values respectively as much as 2,091, 4,835 and 2,600 (>1,96), therefore they are significant toward the accounting information system (AIS).

Figure 2. Matrix of Relationships between AIS and KILK after Bootsrapping

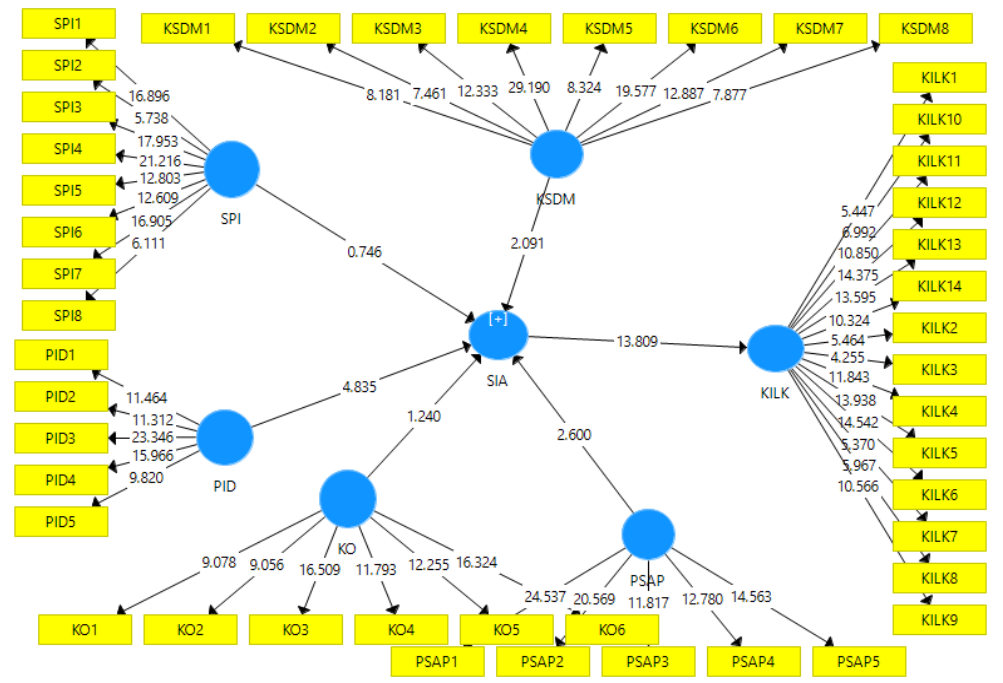

Source : adapted from the data processing by SMARTPLS 3

\section{a) Matrix of Indirect Effect}

In the table 5 below, it can be seen the testing results that the capacity of human resources (KSDM), data input control (PID), and application of SAP (PSAP) significantly influence the accounting information system (AIS), where p-value $<0.05$. Meanwhile, the organizational commitment $(\mathrm{KO})$ and internal control system (SPI) do not influence significantly toward AIS, but the accounting information system significantly influences the quality of financial report information (KILK).

Tabel 5. Indirect Effect

\begin{tabular}{|l|l|l|l|l|l|}
\hline & $\begin{array}{l}\text { Original } \\
\text { Sample } \\
(\mathrm{O})\end{array}$ & $\begin{array}{l}\text { Sample } \\
\text { Mean } \\
(\mathrm{M})\end{array}$ & $\begin{array}{l}\text { Standard } \\
\text { Deviation } \\
(\mathrm{STDEV})\end{array}$ & $\begin{array}{l}\text { T Statistics } \\
(|\mathrm{O} / \mathrm{STDEV}|)\end{array}$ & $\begin{array}{l}\mathbf{P} \\
\text { Values }\end{array}$ \\
\hline KO -> AIS & 0.139 & 0.150 & 0.112 & 1.240 & 0.215 \\
\hline
\end{tabular}




\begin{tabular}{|l|l|l|l|l|l|}
\hline KSDM -> AIS & 0.201 & 0.192 & 0.096 & 2.091 & 0.037 \\
\hline PID -> AIS & 0.325 & 0.322 & 0.067 & 4.835 & 0.000 \\
\hline PSAP -> AIS & 0.192 & 0.200 & 0.074 & 2.600 & 0.010 \\
\hline AIS -> KILK & 0.638 & 0.659 & 0.046 & 13.809 & 0.000 \\
\hline SPI -> AIS & 0.096 & 0.103 & 0.129 & 0.746 & 0.456 \\
\hline
\end{tabular}

Source : data processing results by SMARTPLS 3

b) Matrix of Total Effects of All Variables in the Research

The table 6 below describes direct and indirect effects of all independent variables toward the dependent one, i.e. the quality of financial report information. The organizational commitment (KO) has less significant effect on the variables of AIS and KILK. Therefore, the testing results show that the commitment of organizational leadership boards is not significant on the quality of the financial rport of regional goverment.

Table 6. Total Effect

\begin{tabular}{|l|l|l|l|l|l|}
\hline & $\begin{array}{l}\text { Original } \\
\text { Sample } \\
(\mathbf{O})\end{array}$ & $\begin{array}{l}\text { Sample } \\
\text { Mean } \\
(\mathbf{M})\end{array}$ & $\begin{array}{l}\text { Standard } \\
\text { Deviation } \\
(\mathbf{S T D E V})\end{array}$ & $\begin{array}{l}\text { T Statistics } \\
(\mid \mathbf{O} / \text { STDEV })\end{array}$ & $\begin{array}{l}\mathbf{P} \\
\text { Values }\end{array}$ \\
\hline KO -> KILK & 0.089 & 0.099 & 0.074 & 1.203 & 0.230 \\
\hline KO -> AIS & 0.139 & 0.150 & 0.112 & 1.240 & 0.215 \\
\hline KSDM -> KILK & 0.128 & 0.127 & 0.064 & 1.995 & 0.047 \\
\hline KSDM -> AIS & 0.201 & 0.192 & 0.096 & 2.091 & 0.037 \\
\hline PID -> KILK & 0.208 & 0.212 & 0.045 & 4.570 & 0.000 \\
\hline PID -> AIS & 0.325 & 0.322 & 0.067 & 4.835 & 0.000 \\
\hline PSAP -> KILK & 0.123 & 0.132 & 0.050 & 2.454 & 0.014 \\
\hline PSAP -> AIS & 0.192 & 0.200 & 0.074 & 2.600 & 0.010 \\
\hline AIS -> KILK & 0.638 & 0.659 & 0.046 & 13.809 & 0.000 \\
\hline SPI -> KILK & 0.061 & 0.069 & 0.086 & 0.714 & 0.476 \\
\hline SPI -> AIS & 0.096 & 0.103 & 0.129 & 0.746 & 0.456 \\
\hline
\end{tabular}

Source : adapted from the data processing by SMARTPLS 3

The capacity of human resources has significant influence equally toward both AIS and KILK. The tvalue of the capacity of human resources toward AIS is smaller (0.037) compared with the capacity of human resources toward (0.047). This shows that the capacity of human resources has stronger influence toward AIS than that toward KILK. This also applies on the application of SAP (PSAP) toward KILK. The data input control (PID) has significant influence equally toward AIS and KILK. Therefore, PID has both direct and indirect influence toward KILK. Finally, the internal control system (SPI) does not have significant influence for both AIS and KILK.

c) Results of simultaneous tests

The variables of KSDM, KO, PSAP, PID, SPI simultaneously affects the accounting information system (AIS). It is shown in the following table 7 , with p-value 0.000 and adjusted R2 0.402 . This also applies 
Influence Of The Quality Of Accrual Financial Report Information With The Roles Of Accounting Information System As An Intervening Factor Dyah Purwanti, Ghulbudin Isham Natser on the results of the influence of AIS toward KILK, where AIS has signicant influence toward KILK (p value $0.000)$.

Table 7. Results of determination coefficient tests (Adjusted R2)

\begin{tabular}{|l|l|l|l|l|l|}
\hline & $\begin{array}{l}\text { Original } \\
\text { Sample } \\
(\mathbf{O})\end{array}$ & $\begin{array}{l}\text { Sample } \\
\text { Mean } \\
(\mathbf{M})\end{array}$ & $\begin{array}{l}\text { Standard } \\
\text { Deviation } \\
(\text { STDEV })\end{array}$ & $\begin{array}{l}\text { T Statistics } \\
(\mid \mathbf{O} / \text { STDEV } \mid)\end{array}$ & $\begin{array}{l}\mathbf{P} \\
\text { Values }\end{array}$ \\
\hline KILK & 0.402 & 0.431 & 0.061 & 6.553 & 0.000 \\
\hline AIS & 0.549 & 0.585 & 0.062 & 8.858 & 0.000 \\
\hline
\end{tabular}

Source : adapted from the data procesing by SMARTPLS 3

Based on the hypotheses testings, it can be concluded that the hypothesis 1, 3 and 5 can be accepted, while number 2 and 4 are rejected. From the first hypothesis, we can see that the better the capacity of the human resources of the units within the Ministries/State Agencies in term of accounting and financial report management, the better also the quality of the information generated from the financial report of each agency. In this research, the capacity of human resources is the abilities owned by the officers of SAI (accounting \& financial officers of the Ministries/State Agencies) to be able to mampu generate the financial reports that meet qualitative requirements according to the Government Accounting Standards (accrualbased), so that the financial report of each agency will meet the expected quality. The capacity of human resources is urgently required to improve the quality of accrual financial report information related with the dimensions of personal competencies, understanding of data quality, as well as education and training received.

The research result stating that the capacity of human resources has positive and significant influence toward the accounting information system within the Ministries/State Agencies may be caused by the conditions of human resources which already had adequate educational level for the tasks of accounting management in the agencies, i.e. education level of Diploma III $(48,62 \%)$ and also Strata I (33,95\%). Besides, it known that $37,61 \%$ of the human resources in the Accounting System of Agencies (SAI) within the units that become the respondents also have accounting background. This is supported by the data that the most of the managers of SAI in the units of the Ministries/State Agencies are relatively young, under 35 years old $(88,07 \%)$ who are considered well in mastering the information technology, having adequate intellectualism and analyzing power, as well as abilities to learn/understand the tasks of accounting management and financial reporting better and faster.

Based on the descriptive statistics of the respondents' answers distribution related with the variable of the capacity of human resources, it has been identified that the highest result of the respondents' perception lies on the dimension of understanding the data quality. In this dimension, the accounting officers of the units within the Ministries/State Agencies are considered having adequate understanding toward the importance of the data quality of the accounting information, understanding the use of accounting information in the financial report, as well as understanding the roles and responsibilities of the accounting well. The second highest respondets' perception is the dimension of personal competencies. In this 
dimension, the accounting officers of the units within the Ministries/State Agencies are also considered as have been skillful in using the financial applications in SAI supported with strong and good teamworks.

The organizational commitment has less significant influence toward the accounting information system, and alos indirectly has less significant toward maupun secara tidak KILK. The results of this empirical research are in line with the previous studies conducted by (Choirunisah, 2008) stating that the variable of organizational leaders does not have any significant influence toward the quality of the information, particulary when it is viewed from the information relevancy generated by SAI. The research of (Al-Hiyari, AL-Mashre, \& Mat, 2013) also concluded that the relationships and influence of the management commitment are not significant toward the quality of accounting information.

The research by (Saleh, 2013) on the list of critical success factor influencing the quality if the data information as has been stated by $(\mathrm{Xu}, 2003)$ also concluded that the top management commitment doe not have any significant influence toward the quality of the information/data in the generated financial report. Therefore, the research and testing results also empirically support the critical success factors concluded by $(\mathrm{Xu}, 2003)$. The insignificant influence of the organizational commitment in the research on the units within the Ministries/State Agencies as the working partners of KPPN Jakarta II may be due to less commitment/weak support of the organizational managers, as well as the organizational culture which does not yet fully focus on the data quality. Based on the results of answers distribution and descriptivestatistics analysis on the variable of organizational commitment, it is known that the lowest perception of the respondents is related with the units as the organizations which should focus more on the issue of the data quality. The next lowest perception is about the leaders of the units within the Ministries/State Agencies who have provided sufficient human resources budget and facilities needes to ensure the quality of the financial report information.

The results of the hypotheses testings indicate a phenomenon that AIS used by the units within the Ministries/State Agencies statistically influences the quality of the accrual financial report. These results are very interesting to be identified, where they are in line with the results done by (Saleh, 2013) stating that AIS (AIS Suitability) has significant influence toward the quality of the data/information in the generated financial report. Therefore, the results of the research and testings also empirically support the critical success factors stated by $(\mathrm{Xu}, 2003)$, where one of the most influential factors for the quality of the data/iformation is the AIS suitability used by the organizations.

The significant impacts of AIS on the studies on the units of the Ministries/State Agencies as the work partners of KPPN Jakarta II may be due to the support from the accounting and financial reporting applications applied currently (especially SAIBA) which are very important fro the users, and the constraints faced by the operators of the work units. SAIBA is designed and started to be applied in 2015 because SAKTI (Sistem Aplikasi Financial Application System of Agencies) which was originally designed and developed particularly for the AIS and to cover the accrual-based financial recording, until the end of 2014 it was not yet ready to be applied. The research and testing results also empirically support the critical 
success factors stated by $(\mathrm{Xu}, 2003)$, where one of the most influential factors is the quality of the data/information generated through the input control by the application system/AIS.

The significant influence of the input control toward the studies of the units within the Ministries/State Agencies as the wor partners of KPPN Jakarta II may be due to better accounting data input process done by the operators of SAI / managers of the units, although there are still some mistakes in the accounting data input, and etc. Besides, it can be also that there are still some essential problems in the process of check \& balance (reconciliation) of the data from KPPN and the units of the Ministries/State Agencies in 2015.

Based on the results of confirmation and interviews toward Verification \& Accounting Section of KPPN Jakarta II, it is identified that there are many units of the Ministries/State Agencies which are too late in implementing the reconciliation based on predetermined deadline, i.e. over the date of 10 for each month yakni. Some factors causing their lateness are the complexity of the financial transactions on the units so that the data input process take longer time and many mistakes made furing the input process, from both the untis and KPPN. Besides, unexperienced accounting operators and new units that hold the reconciliation process for very first time are considered as the main obstacles in the reconciliation process. Many units of the Ministries/State Agencies which do not implement the reconciliation on time cause the reconciliation targets of IKU in KPPN Jakarta II are not achieved completely in 2015.

According to the result of hypothesis 5 testing, it can be explained that the better of the application of SPI by the units of the Ministries/State Agencies particularly in temr of accounting management and financial repor preparation, the better also the quality of the information generated in the financial report of each agency. The results of this empirical studies support the previous studies done by (Aryani, 2013), Windiastuti (2013), and Mahaputra (2014) which also stated that SPI significantly influences the quality of financial report information. However, this research also supports the result of (Choirunisah, 2008) concluding that SPI has less significant impacts. The Application of Government Accounting Standards has a positive correlation with the accounting information system in the units of the Ministries/State Agencies. The significance value of the application of SAP is $0.000(<0.05)$. It shows that the application of SAP has significant influence toward the accounting information system of the units of the Ministries/State Agencies.

Based on the result of hypothesis 6 testing, it can be concluded that the better the application and implementation of SAP according to government rule number 71/2010 (PP 71/2010) in the units of the Ministries/State Agencies, the better also the quality of information generated in the financial report of each agency, assisted by better accounting information system. This empirical result is in line with the previous studies done by Aryani (2013), Juwita (2013), and Mahaputra (2014) explaining that the application/implementation of SAP has significant influence on the quality of financial report information.

In this research, the application of SAP is closely related with all efforts done and results achieved in the implementation of systematic and structured activities on each period of financial reporting for each accounting entity. The units of the Ministries/State Agencies have an obligatory to implement the accounting process and prepare the financial report to provide important information for the good and accountable national financial management. The financial report of each unit within the Ministries/State 
Agencies prepared with the application of SAP (accrual-based) consistently will play very important roles in terms of accountability, management, transparency, intergeneration balance, as well as performance evaluation (PP 71/2010). Thise five matters are included as the variable of the application of SAP in this research.

\section{CONCLUSIONS}

This research aims to identify, analyze, an examine empirically the influence of the capacity of human resources, organizational commitment, accounting information system, input control, internal control system, as well as the application/implementation of SAP toward the quality of accrual-based financial report information of the work units within the Ministries/State Agencies in term of KPPN payment of Jakarta II for fiscal year 2015. From the results of empirical and analytical testings, it can be drawn some conclusions as follows:

a. The capacity of human resources, application of SAP and data input control significantly influence the quality of financial report information, while the organizational commitment and internal control system do not have any significant effects toward the practice of accounting information system.

b. The application of accounting information system significantly influences the quality of financial report information.

\section{REFERENCES}

Al-Hiyari, A., AL-Mashre, M. H. H., \& Mat, N. K. N. (2013). Factors that affect accounting information system implementation and accounting information quality: A survey in University Utara Malaysia. American Journal of Economics, 3(1), 27-31.

Ariesta, Fadila. 2013. Pengaruh Kualitas Sumber Daya ManuAIS, Pemanfaatan Teknologi Informasi, dan Pengendalian Intern Akuntansi Terhadap Nilai Informasi Pelaporan Keuangan Pemerintah Daerah (Studi Pada Satuan Kerja Perangkat Daerah di Kabupaten Pasaman Barat). E-Jurnal Skripsi. Fakultas Ekonomi. Universitas Negeri Padang. Padang.

Aryani, F. (2013). Analisis Faktor-Faktor Yang Mempengaruhi Kualitas Laporan Keuangan Kementerian Negara/Lembaga Satuan Kerja Mitra KPPN Medan II.

Choirunisah, F. (2008). Faktor-faktor yang mempengaruhi kualitas informasi laporan keuangan yang dihasilkan sistem akuntansi instansi. Yogyakarta: Tesis UGM.

Committee of Sponsoring Organizations (COSO) of the Treadway Commission. 2013. Internal Control Integrated Framework - Executive Summary.

Fanani, Zaenal. 2009. Kualitas Pelaporan Keuangan: Berbagai Faktor Penentu dan Konsekuensi Ekonomis. Jurnal Akuntansi dan Keuangan Indonesia Volume 6 - Nomor 1.

Handayani, D. (2012). Good Governance dan Kualitas Laporan Keuangan Pemerintah. Jurnal Akuntansi Keuangan Dan Bisnis Vol, 12, 12-16.

Indriasari, Desi dan Ertambang Nahartyo. 2008. Pengaruh Capacity of human resources, Pemanfaatan Teknologi Informasi, dan Pengendalian Intern Akuntansi Terhadap Nilai Informasi Pelaporan Keuangan Pemerintah Daerah (Studi Pada Pemerintah Kota Palembang Dan Kabupaten Ogan Ilir). Simposium Nasional Akuntansi (SNA) XI Pontianak. 
Influence Of The Quality Of Accrual Financial Report Information With The Roles Of Accounting Information System As An Intervening Factor

Dyah Purwanti, Ghulbudin Isham Natser

Jonas, Gregory J. and Jeannot Blanchet. 2000. Assessing Quality of Financial Reporting. AAA Accounting Horizons: September 2000, Vol. 14, No. 3, pp. 353-363.

Lubis, Nurliza. 2014. Analisis Faktor-Faktor yang Mempengaruhi Quality of financial report information Pemerintah Kota Medan. Skripsi. Fakultas Ekonomi. Universitas Muhammadiyah Sumatera Utara: Medan.

Milal, Ahmad Zainul. 2013. Makna Opini Audit WTP Bagi Kementerian / Lembaga (Studi Kasus Pada Kementerian SoAISl). Universitas Brawijaya.

Nobes, Christopher W. and Christian Stadler. 2014. The Qualitative Characteristics of Financial Information, and Mangers' Accounting Decisions: Evidence from IFRS Policy Changes. Lancaster University Management School Lancaster, Lancashire, LA1 4YX, UK. . Peraturan Pemerintah Nomor 71 Tahun 2010 tentang Standar Akuntansi Pemerintahan. . Peraturan Pemerintah Nomor 60 Tahun 2008 tentang Internal control system Pemerintah (SPIP).

Saleh, F. M. (2013). Critical success factors and data quality in accounting information systems in Indonesian cooperative enterprises: An empirical examination. Contemporary Research in Business, 5(3).

Sekaran, Uma. 2003. Research Methods For Business - A Skill Building Approach $4^{\text {th }}$ Edition. John Wiley \& Sons, Inc: USA.

Silviana. 2012. Pengaruh Komitmen Kepala Daerah Terhadap Kualitas Laporan Keuangan Pemerintah Daerah di Provinsi Jawa Barat. Seminar Nasional Akuntansi \& Bisnis (SNAB) 20=012. Bandung 27 Maret 2012.

Soimah, Siti. 2014. Pengaruh Capacity of human resources, Pemanfaatan Teknologi Informasi dan Pengendalian Intern Pemerintah Terhadap Kualitas Laporan Keuangan Pemerintah Daerah Kabupaten Bengkulu Utara. Skripsi. Fakultas Ekonomi dan Bisnis. Universitas Bengkulu: Bengkulu.

Sukmaningrum, Tantriani. 2012. Analisis Faktor-Faktor yang Mempengaruhi Quality of financial report information Pemerintah Daerah (Studi Empiris pada Pemerintah Kabupaten dan Kota Semarang). Skripsi. Universitas Diponegoro: Semarang.

Suryana. 2010. Metodologi Penelitian Model Praktis Penelitian Kuantitatif dan Kualitatif. Buku Ajar Perkuliahan. Universitas Pendidikan Indonesia.

Van Beest, Ferdy, Geert Braam, \& Suzanne Boelens. 2009. Quality of Financial Reporting : Measuring Qualitative Characteristics. Working Paper. Institute for Management Research, Radboud University Niymegen. Page: 316.

Warisno. 2009. Faktor-Faktor yang Mempengaruhi Kinerja Satuan Kerja Perangkat Daerah (SKPD) Di Lingkungan Pemerintah Provinsi Jambi. Tesis Sekolah Pascasarjana. Universitas Sumatera Utara: Medan.

$\mathrm{Xu}, \mathrm{H}$. (2003). Critical success factors for accounting information systems data quality. University of Southern Queensland.

$\mathrm{Xu}, \mathrm{H}$. (2015). What Are the Most Important Factors for Accounting Information Quality and Their Impact on AIS Data Quality Outcomes? Journal of Data and Information Quality (JDIQ), 5(4), 14.

Xu, H., Horn Nord, J., Daryl Nord, G., \& Lin, B. (2003). Key issues of accounting information quality management: Australian case studies. Industrial Management \& Data Systems, 103(7), 461-470.

Zuliarti. 2012. Pengaruh Capacity of human resources, Pemenfaatan Teknologi Informasi, dan Pengendalian Intern Akuntansi Terhadap Nilai Informasi Pelaporan Keuangan Pemerintah Daerah: Studi Pada Pemerintah Kabupaten Kudus. Skripsi Universitas Muria: Kudus. 